TILTAI, 2015, 1, 83-98, ISSN 1392-3137 (Print), ISSN 2351-6569 (Online)

\title{
ECOLOGICAL NETWORK AS A MULTI-LEVEL SPATIAL PLANNING TOOL FOR BIODIVERSITY CONSERVATION: ANALYSIS OF AN ESTONIAN CASE STUDY
}

\author{
Kadri Tillemann, Monika Suškevičs, Mart Külvik \\ Tallinn University of Technology, Estonian University of Life Sciences
}

\begin{abstract}
The Estonian concept of ecological networks (the Green Network) is implemented at different administrative levels by including multiple stakeholders. Building ecologically coherent Green Infrastructure is also one strategic aim of the European Union's environmental policy. An embedded case study shows that contradictions between governance levels and ineffective stakeholder involvement measures have caused negative influence on land use decision-making processes on a local level. We further identified that the process of integrating the ecological network concept into the land use planning system has characteristics of vertical decentralisation, but the lack of relevant coordination have precluded achieving satisfactory results regarding stakeholder involvement and co-operation. KEY WORDS: ecological networks, green infrastructure, multi-level governance, stakeholder participation, spatial planning.
\end{abstract}

\begin{abstract}
Anotacija
Estų ekologinių tinklų (žaliụjų tinklų) samprata diegiama įvairiais administraciniais lygmenimis įtraukiant ne vieną suinteresuotą šalį. Ekologiškai nuoseklios žaliosios infrastruktūros kūrimas yra ir vienas Europos Sąungos aplinkosaugos politikos uždavinių. Straipsnyje pristatoma atvejo analizė atskleidžia, kad prieštaravimai tarp valdymo pakopų ir neefektyvus suintresuotujų šalių ịtraukimas neigiamai veikè vietinio lygmens sprendimus dèl žemès naudojimo. Tyrimas taip pat atskleidé, kad ekologinio tinklo ịtraukimas ị vietinio lygmens žemès naudojimo planavimą turi vertikalios decentralizacijos bruožų, bet tinkamo koordinavimo stoka bendradarbiaujant ir įtraukiant suinteresuotas šalis neleidžia pasiekti norimų rezultatų.

PAGRINDINIAI ŽODŽIAI: ekologiniai tinklai, žalioji infrastruktūra, daugiapakopis valdymas, suinteresuotų šalių dalyvavimas, teritorijų planavimas.
\end{abstract}

DOI: http://dx.doi.org/10.15181/tbb.v69i1.1052

\section{Introduction}

Spatial planning can help to deliver economic, social and environmental benefits. Correctly administered, it is an important tool for promoting investment, development, environmental improvements and quality of life (United Nations..., 2008). Having a significant impact on the economy, the environment and social welfare, it has obtained a crucial role in policy-making as regards all governance levels. Routine policy-making occurs through a variety of different modes and 
combinations of modes. It deploys a myriad of different policy instruments and engages different constellations of member states within diverse institutional frameworks (Wallace et al., 2010). It is especially the case if spatial planning deals with biodiversity conservation issues. Sustainable management of biological diversity is one part of sound land use decisions at different policy levels. 'Ecological network' is a concept deriving from landscape ecology; it aims at preserving the connectivity between natural areas in order to guarantee the migration and dispersal opportunities for species, as well as to ensure the continuation of material and energy flows (Bennett, 2004; Jongman et al., 2004). The national concept of ecological networks in Estonia - Green Network - is among the most important tools for integrating holistic landscape management concerns into sectoral policies (Mander et al., 1988; Sepp \& Kaasik, 2002; Külvik et al., 2003).

As spatial planning is now widely understood as an interactive process, undertaken in a social context, rather than being a purely technical process of design, analysis and management (Healey, 1997) it has became clear that a sustainable implementation of ecological networks needs stakeholder involvement in all phases of the policy cycle to reach acceptance by the various stakeholder groups (Tieman, Siebert, 2009). The essence of analysing policy and governance networks derives from the assumption that the structure and content of relationships between stakeholders are likely to influence outcomes of policy processes (Rhodes, 2007). Relations and interaction between governmental levels in multilevel governance systems affect public organisations, their tasks, functioning and autonomy. Through various means stakeholders and external scrutinisers can also effect relations of horizontal and vertical accountability and control, and the governance and autonomy of public organisations (Lægreid et al., 2008). The administrative bodies responsible for qualitative spatial planning decisions face great challenges as stakeholder involvement cannot be characterised as an uncomplicated and uniform tool to guarantee success in spatial planning processes: the scale, governance level, stakeholders' type and other characteristics have to be considered. The degree of stakeholder participation may vary in intensity - from passive participation to selfinitiated mobilisation (Pretty et al., 1995).

During the planning process, local stakeholders should be seen as experts for planning in the same way as scientists and landscape planners because of their expertise on the local conditions (Erdmann et al., 2004). This principle could be brought into practice through vertical decentralisation of governance, which includes the transfer of authority, functions, responsibilities and resources from central government to local government structures (Niikawa, 2006). It is relevant to consider the vertical decentralisation in case of biodiversity governance as well as 
local governance, especially when strongly participatory, is more likely to lead to ecologically rational outcomes than governance on higher spatial scales (Leach et al., 2002).

The current paper explores the integration process of the ecological network concept into the Estonian planning system as an example of the vertical decentralisation and specialisation by describing and evaluating the efficiency of planning process and observing the outcomes on the local level implementation phase.

Therefore, within an embedded case study, several case studies from all three governance levels have been completed. At first the integration of ecological network from national level legislation into regional and local levels in Estonia is explored. Further on, the regional level is more closely observed by dealing (Harju County, regional level) with regional planning documents' influence on local planning as well as with stakeholder networks and knowledge exchange within the planning and implementation of the Estonian ecological network concept. In order to analyse the local implementation phase the case study (Keila Rural Municipality) concerning stakeholder relations and information flows in integrating biodiversity knowledge into local decision-making was conducted as well as the relevant building and planning activities at local governance level was thoroughly analysed.

The relevance of the concept in European Union policies has been significantly increased when the European Commission in May 2011 adopted a strategy to halt the loss of biodiversity and ecosystem services in the EU by 2020 with a strategic target to maintain and enhance the ecosystems and their services by establishing green infrastructure by 2020 (European Commission, 2011). To that effect, in May 2013 the European Commission has adopted a Green Infrastructure (GI) Strategy in the form of a Communication from the Commission: 'Green Infrastructure - Enhancing Europe's Natural Capital' (European Commission, 2013). GI is perceived as a potentially useful concept for communication the importance of biodiversity conservation and ecosystem services provision to the public and decision-makers (Albert \& Von Haaren, 2014). The need to include all governance levels into the process of GI is recognised at EU level - EU Committee of the Regions (CoR) in it's opinion "Green infrastructure - enhancing Europe's natural capital" (Committee of the Regions, 2013) emphasises that the key to successful GI deployment lies in the cooperation between all governance levels and in the effective implementation of multilevel governance (MLG) principles as well as in participation of all parties and stakeholders, including local residents, in its development and implementation. Furthermore CoR urges local and regional authorities to take steps 
in all the relevant sectoral policies, in particular through their spatial and urban planning responsibilities, to plan and organise green infrastructure.

Therefore relevant knowledge about governance challenges about the usage of this biodiversity preservation tool, with a specific emphasis on local and regional governance level, will be essential for further activities in other member states as well.

The general objective of the study is to observe and analyse the integration process of the ecological networks concept into the Estonian planning system in various governance levels. The focus is on local and regional governance levels and the aim is to identify and describe the strengths and weaknesses of the process and to associate them with relevant public administration theories.

\section{Methods}

An embedded case study about integration of the ecological network concept into the Estonian planning system forms the basis of the current paper. Within this study, four case studies were carried out in order to gather data and information from all relevant administrative levels in order to describe the biodiversity governance while implementing the Green Network concept in Estonia. The objective is to study the ecological network implementation processes within and between governance levels including:

- two case studies about national guidelines' implementation at a regional and local level (Tani, 2007; Kivimaa, 2008), including the content analysis of the national ecological network planning system;

- case study on stakeholder involvement at different levels;

- local level implementation analysis in one rural municipality (Koort, 2010).

At first an overview of the national background of ecological network planning and implementation from the stakeholder participation perspective is presented, and its influence on regional and local governance levels is analysed. To assess mutual adjustment of ecological network delineation in the land use plans at regional and local level, a comparative study of planning documents was carried out by a meta-analysis of two topical studies analysing and comparing Green Network planning practices at county and municipality levels (Kivimaa, 2008) and focusing on examples of network implementation in a particular county (Tani, 2007). These studies have integrated comparative reviews of textual and cartographical planning documents and interviews with representatives of 
the key stakeholder groups. The first study assessed the thematic planning of five Estonian counties and the comprehensive planning of eight municipalities (Keila, Kernu, Nõo, Saue, Sõmeru, Toila, Tähtvere and Õru municipalities). The second one focused on Harju county and all of its 18 rural municipalities. The region embraces surrounding areas of the Estonian capital city Tallinn. The case study region has been selected due to its vicinity to the capital city and because of the consequent distinctive intensity of land use development, land conversion and resultant social reactions and reflections, especially in the context of Green Network and nature conservation requirements. An in-depth GIS analysis was carried out to find out differences between county level and municipality level Green Network elements.

In order to evaluate the stakeholder involvement from different levels a case study about participatory decision-making in pursuing sustainable land use policies was carried out. The case study concentrated on the implementation of ecological networks in Harju County (1). The study included 33 face-to-face or telephone interviews with key stakeholders from different decision-making levels (national, regional, local) and land-use sectors (spatial planning, agriculture, nature conservation, forestry, hunting, transport, construction), together with the textual analysis of documents regarding participation. Interviews were conducted according to an interview form which included mostly open-ended questions for discussing interviewees' duties and interests with regard to the Green Network and other relevant stakeholders, experiences with participatory approaches and participants' views on the effectiveness of those events.

The last step was to analyse all land use decisions regarding planned ecological network within local case study area (Keila Rural Municipality) in order to observe and evaluate the impact of the national and regional level decision making on the ground. Therefore all the construction permits and detailed planning documents within the period of 2003 to 2010 were analysed and the ones directly affecting Green Network structural elements were selected - there were 73 issued building permits and 36 initiated detailed plans. The selected administrative documents were processed by map analysis, tabular analysis and observation. The GIS analysis based on CORINE land cover map, Estonian Basic Map and Estonian Land Price Zones Map (Koort, 2010). 


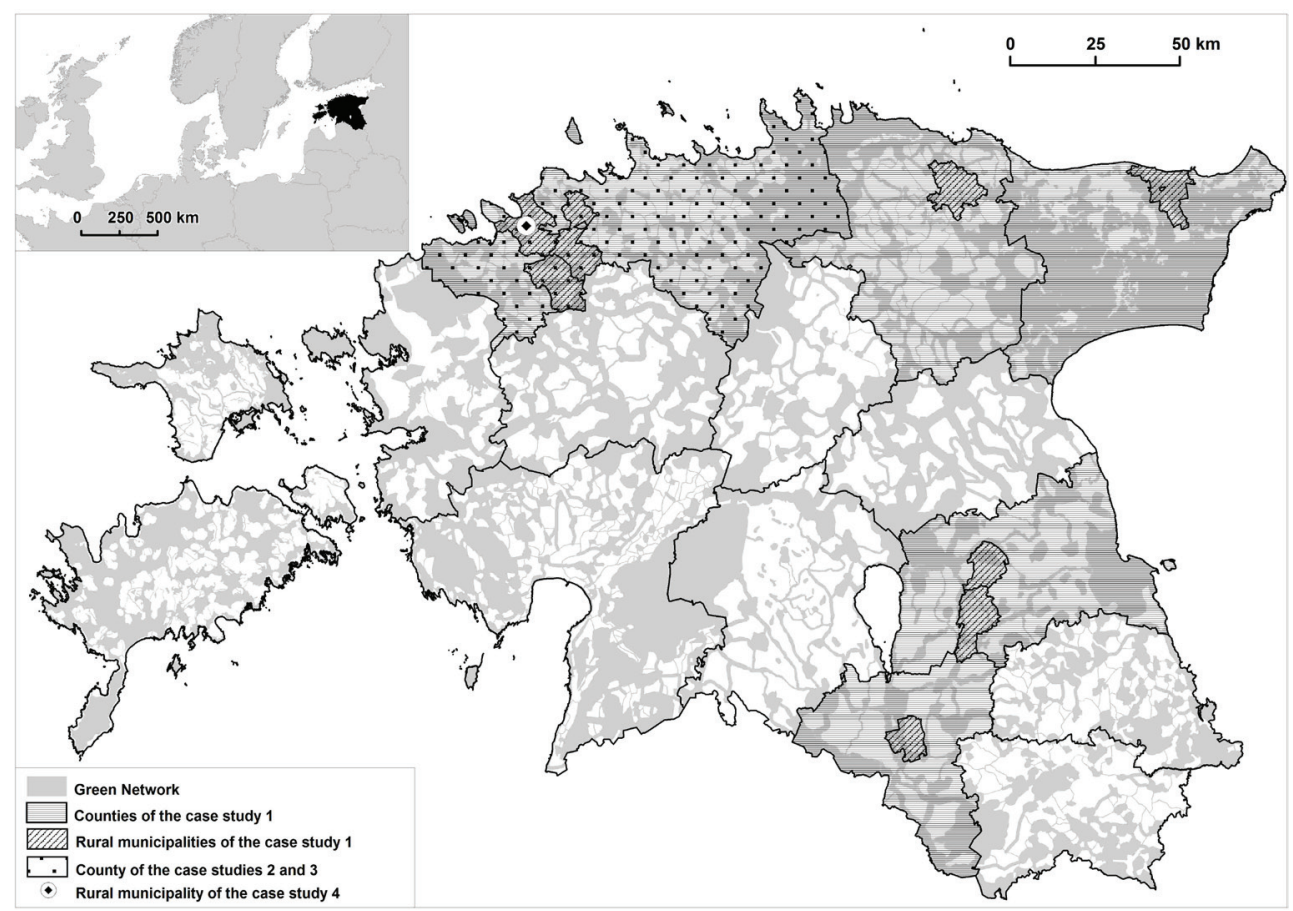

Fig. 1. Location of the case study areas

\section{Results}

\subsection{Stakeholder networks and knowledge exchange in the Green Network development}

\subsubsection{Structure of Green Network development}

The Green Network development in Estonia is integrated into the spatial planning system which is organised around basic administrative units of Estonia: country - national plan; counties (regional level) - county plans; municipalities (local level) - comprehensive plans. The Green Network is, at various degrees of specification, addressed at all these levels of land use planning. First, the national long-term spatial plan - 'Estonia 2010', approved by the government in 2000 delineates basic principles of the Estonian ecological network (Estonian..., 2001) by establishing ecological corridors and 12 core areas of national and international importance. These principles are kept in the new Estonian national spatial planning policy 'Estonia 2030+' (National..., 2013), among its main objectives are the 
connectivity of the green network and the preservation of the landscape values. Second, at county level, the Green Network is one sub-theme of county thematic planning. In 1999, the second phase of county planning (thematic planning) was initiated which aims at defining environmental conditions for the development of land use and settlement. Third, at the municipal level, according to the Act on Planning (came into force in 2003), the Green Network is required as one topic in the comprehensive plan - the latter is the planning document for a whole municipality which sets general land use and building conditions. The plan should specify the boundaries of the Green Network delineated in county thematic plans and lay down requirements for land use within the Green Network at a local level. Within this paper the cases of Harju County and Keila Rural Municipality will be analysed further. Harju County's thematic planning - including Green Network map - came into force in March 2003. In the beginning of 2004, Keila Rural Municipality Government started to prepare its current comprehensive planning document to come into force in October 2005. Keila Rural Municipality planning included adapted and specified maps of the Green Network and some minor requirements for land use.

\subsubsection{Identifying stakeholders and analysing their relationships}

Content analysis of the interviews with stakeholders revealed that a wide variety of actors from governmental, private, and civil society spheres and from different policy levels are connected to Green Network issues through their responsibilities, interests and various other ways that affected the development of the network.

According to Estonian planning law, the spatial planning sector is responsible for sustainable land use planning at national, regional and local levels. Spatial planning sector include the Estonian Ministry of Interior (MoI), the related governmental institutions at lower administrative levels (county and local governments), and spatial planning companies who advise governmental spatial planners technically and content-wise on ecological network issues. The relationships between the MoI (national level), county governments (regional level) and municipalities (local level) are hierarchical. Each level is responsible for compiling land use plans where the Green Network is delineated. The higher levels of government are responsible for observing the conformity of lower levels' spatial plans.

The Ministry of Environment (MoE) and its subdivisions (county environmental departments, State Nature Conservation Centre) act as environmental advisors for spatial planning stakeholders regarding the processing of detailed or compre- 
hensive plans. Scientists have elaborated the national ecological network methodology which is applied at regional and local level to incorporate connectivity issues into land use plans at respective levels (Sepp et al., 2002). In contrast, the Estonian $\mathrm{MoE}$ and related governmental nature conservation stakeholders and environmental NGOs are in a somewhat marginal position as regards Green Network development in Estonia, perhaps because of their limited legal power regarding Green Network decisions (in the case of governmental nature conservation stakeholders), or their low activity and awareness in connectivity issues specifically (in the case of environmental NGOs). This is despite the fact that these actors were regarded as very important by our respondents, because the ecological network issues are perceived to be their area of expertise. Similarly, our respondents regarded local people as very important actors in Green Network issues but in reality they are not very active participants or, if they are, they have not been given much power by the decision-makers. Moreover, the main stakeholders with rather conflicting interests regarding the Green Network, representing infrastructure development, building, forestry and other resource use sectors are currently rather weakly involved in the discussions on the Green Network topic.

Our respondents considered the public hearings effective in terms of information distribution from the ecological network experts to other stakeholders. However, in general, the formal participatory processes required by law were seen as quite ineffective because of several reasons, e.g. time constraints, low commitment by the conveners of the process to involve the public, lack of proper facilitation of public meetings (in order to encourage dialogue and to produce meaningful outcome), or poor information distribution about the opportunities to participate.

\subsection{Environmental information delivery and stakeholder cooperation in land use governance in the Keila Rural Municipality}

\subsubsection{Decision-making framework at local level}

A governance framework on spatial planning and environmental spheres in the case study area can be described as follows (see also Fig. 2). The government at regional level (County Government) supervises the decisions on comprehensive planning at local level (Local Government). Regional offices of the Estonian Environmental Board (national level) have an advisory role. Decisions concerning other environmental subjects (Environmental Impact Assessment (EIA) and Strategic Environmental Assessment (SEA), protected areas, environmental management) are made by local government or local council depending on the subject and 
importance of the decision. Generally in decision-making processes concerning environment impact assessment and spatial planning, some public consultation is obligatory, enabling stakeholders to influence the process.

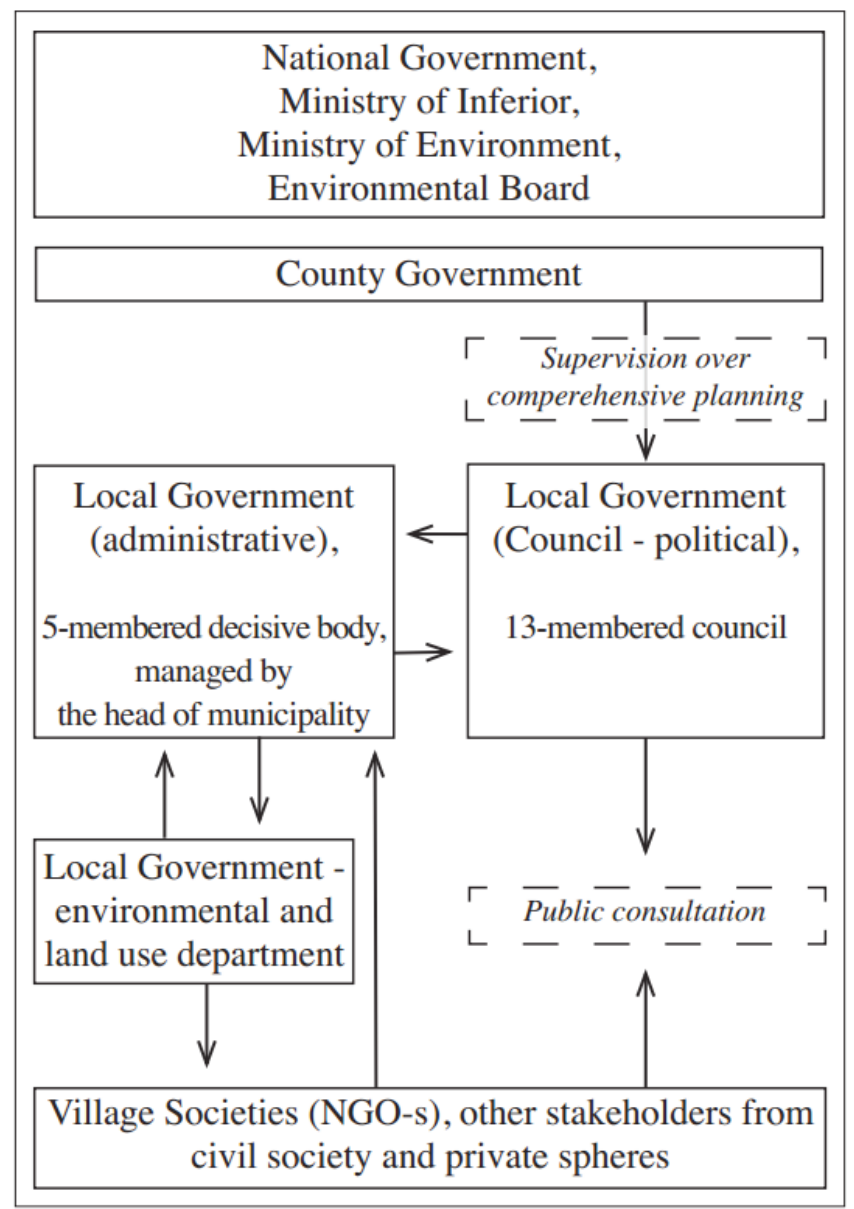

Fig. 2. Local governance framework on land use planning in Estonia

\subsection{Results from a comparative study of planning documents}

The formal method for specifying the Green Network in thematic plans was followed in all counties studied and its implementation was found to be reasonably uniform, as methodological material 'Environmental conditions for settlement and land use' (Sepp, Jagomägi, 2002) was used in all counties to compose a thematic planning document. Minor differences between counties occur in chapters 
reflecting the basic reference data and in sections specifying the requirements and restrictions for land use.

Clear differences in methodology were distinguishable between comprehensive plans set up by municipalities. In several cases the method for specifying the Green Network had not been applied and the contents of the explanatory section often contradicted the maps. Frequently, the structural elements of the network (i.e. core areas, corridors, neutral areas) had not been distinguished from one another. There was no reference in comprehensive plan documents to the formal method for specifying the Green Network. However, 'environmental conditions for settlement and land use' have been considered in most of the cases. The adaptations made to thematic county plans in municipality's comprehensive plans were mostly enlargement or diminution of core areas or corridors or, less often, displacement of corridors. No displacement of core areas was recorded (Fig. 3).

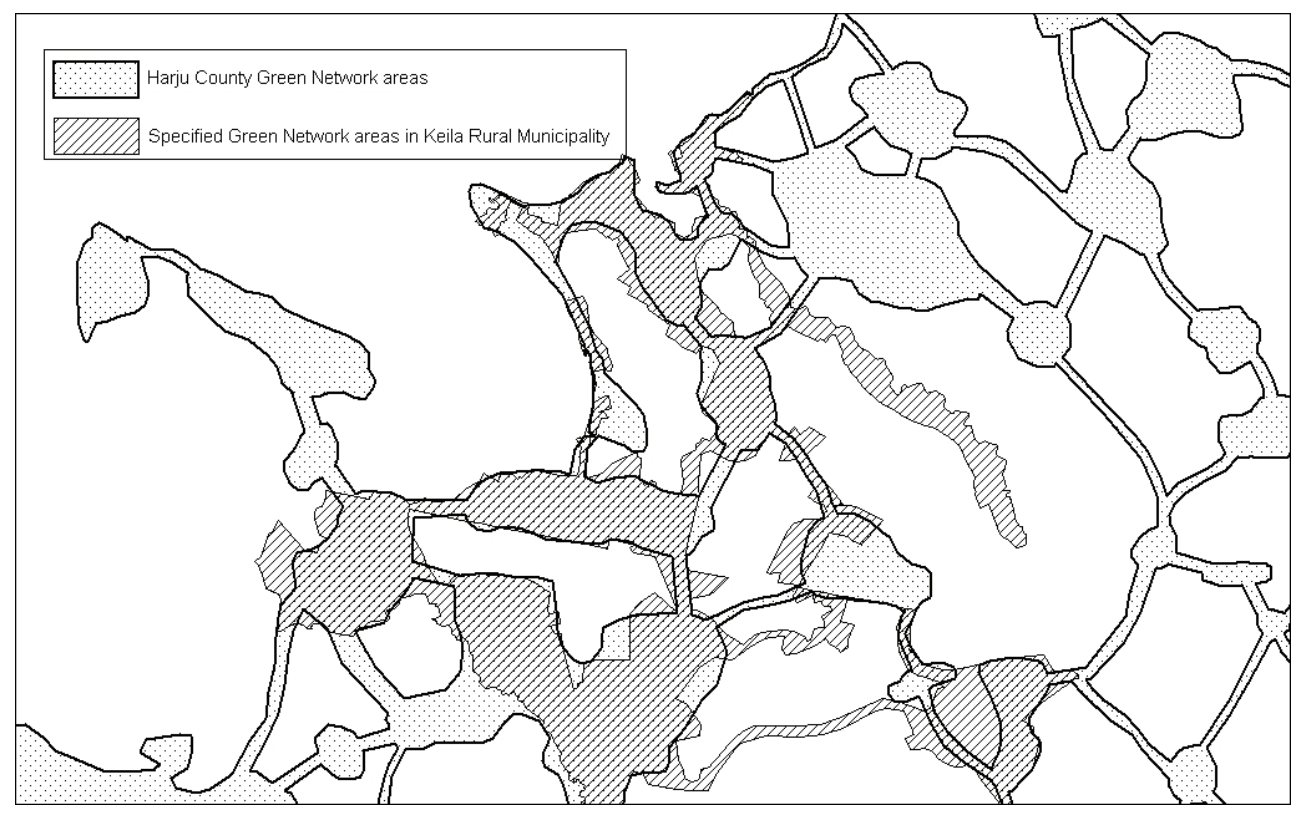

Fig 3. The comprehensive plan at municipal level specifies the boundaries

of the Green Network delineated in county thematic plans and lays down requirements for land use within the Green Network at the local level. Example of Keila Rural Municipality, Harju County, Estonia

The range of ways in which the Green Network was addressed by municipalities in comprehensive plans reflected the variety of consultants involved by different local authorities. However, the absence of a specific methodology for identifying the Green Network as a component of comprehensive plans could be 
considered as the main reason for inconsistencies in planning practice at municipality level. This result was reflected by the more general analysis from all counties as well as from the in-depth analysis of one (Harju) county where a similar variety of problems occurred within the smaller region. In addition to the results from general analysis the case of Harju County showed that local municipalities are relatively unmotivated to be actively involved in Green Network planning. A closer look at one municipality (Keila Rural Municipality) with a GIS analysis showed the presence and necessity of specification of Green Network planning on a local level scale. Using locally available data and knowledge for the comprehensive planning document in order to accurately meet the needs of local level decisionmaking, is of paramount importance.

\subsection{Results from an analysis of land use decisions}

In the case of Harju County the thematic planning 'Environmental conditions for settlement and land use' came into force in 2003 and from there to 2005 when the Green Network was adapted and integrated into the local level comprehensive planning document, all construction permits as well as detailed planning documents had to be in accordance with county thematic plan. After 2005, when Keila rural municipality comprehensive planning document with extensive improvements and specification regarding Green Network elements became valid, construction permits and detailed planning documents were based on the updated legislative basis. The analysis of land use decisions made at local level showed that $57 \%$ of those within the Green Network were adopted before a local level planning document came into force within the period 2003-2005. The rest of the $43 \%$ of the decisions were made during the longer period (2006-2010), therefore it could be concluded that local authorities were more willing to implement the planning document adapted and specified by themselves.

\section{Discussion}

The attempt to identify the inclusion of relevant stakeholders from different levels was based on a regional-level case study in Harju County. The results of the study give a general overview of stakeholder groups that are of relevance to Green Network development in Estonia. The identification of stakeholders and their relationships on the basis of the study in Harju County shows that there are various interactions between the actors gathered around Green Network development. However, many of the affected stakeholders do not know much about the concept 
and have so far remained rather far from the central discussions about the issue. At the same time, for those stakeholders directly responsible for the planning and implementation of the Green Network, participating in discussions on the Green Network topic is an inherent part of their regular activities. Despite this, the latter group of actors still have difficulties in defining and sharing their exact responsibilities regarding the Green Network.

The study in Harju County provides an overview of participatory arenas most common in the Green Network issues. It also shows how these arenas are evaluated by the stakeholders in terms of their general effectiveness (e.g. to provide a genuine arena for deliberation). The study identified some positive examples in terms of knowledge transfer between different stakeholders, such as, between scientists and policymakers and between some resource user groups and spatial planners. Personal and informal contacts are important catalysts for mutual cooperation between local government and other stakeholders but the content of this cooperation might not be easy to capture with a standard-format enquiry tool, as the case study in Keila Municipality demonstrated.

Integrating the new task of Green Network planning into the Estonian spatial planning system has clear characteristics of vertical specialisation in terms of public management as the 'differentiation of responsibility on hierarchical levels, describing how political and administrative tasks and authority are allocated between forms of affiliation' (Lægreid et al., 2003) are present in the process. Vertical decentralisation requires shifts in central government policy, laws, as well as institutional and structural arrangements to provide for the sharing of powers, authority, functions and resources, thus enabling local governments to perform fully (Niikawa, 2006). The importance of local context has been shown in many different planning policy areas (Bellandi, Caloffi, 2010) and is indeed a key issue for the implementation of policy throughout Europe, particularly in relation to landscape planning (Llausas, Roe, 2012).

The connection and balance between specialisation and coordination is important. Increasing specialisation implies a need for greater efforts at coordination, at least if the level of overall coherence of policy and services is to be maintained. Otherwise, the danger is that newly specialised agencies will go their own ways (Bouckaert, Pollitt, 2004). Coordination in a public sector inter-organisational context is understood as 'the instruments and mechanisms that aim to enhance the voluntary or forced alignment of tasks and efforts of organisations within the public sector. These are used in order to create a greater coherence, and to reduce redundancy, lacunae and contradictions within and between policies, implementation or management' (Peters, 1998). The case study's results about the planning and implementation of the ecological network concept revealed some gaps which 
precluded achieving satisfactory results regarding stakeholder involvement and co-operation between governance levels. From the description of the Estonian spatial planning system and the integration of ecological network concept into the relevant legislation and guidelines we saw that the coordination from national level was almost fully neglected after the legislation came into force and regional thematic planning documents were compiled in accordance with methodological guidelines. The system does not include any effective coordination mechanism between regional and local level - the supervisory function of county government over local authorities are dealing mostly with consequences rather than putting an input into effective policy making. As a result, local authorities' admit their need for a more accurate and wider range of information for environmental decisions and they are not highly motivated to deal with specific issues such as Green Network planning. Regarding implementation, our analysis shows that if the ecological network was effectively integrated into local comprehensive planning documents, less land use decisions interfering with the network were made.

\section{Conclusions}

Our study shows that the ecological network is integrated into all levels of the Estonian spatial planning system - national, regional and local mainly in legal terms. However, as it becomes apparent on the basis of our research results, it is not only legislative requirements that determine the efficiency of ecological network planning and implementation. Our study shows certain gaps in stakeholder involvement and co-operation within and between governance levels during the planning phase: stakeholders' dissatisfaction with the participation tools used, varying quality of local level Green Network planning documents as well as the inadequate inclusion of particular stakeholders such as the Ministry of Environment or environmental NGO's. The consequences of deficiencies are reflected in subsequent implementation phase. We found out that contradictions between different governance levels and ineffective stakeholder involvement measures have caused negative influence on land use decision-making processes on a local level.

The main framework for local government's decision-making practice are statutory legal requirements. This brings up two actual threats to efficient administrative decentralisation:

1. the local government representatives find the fulfilment of legal prescriptions to be sufficient and effective and their attitude can be an impediment for committing themselves to improving participatory approaches at the local level; 
2. being aware and following a rather narrow range of statutory requirements only, local authorities are distanced or even unaware about the conceptual essence and objective of the Green Network and therefore unable to effectively implement it.

In contrast to the view held by local government representatives, on a countrywide scale, several stakeholders of the Green Network development consider the formal participatory measures in land use governance as ineffective. These contradicting positions refer to insufficient coordination and flows of information within the components of multilevel governance structures.

Sustainable land use governance extends over different administrative levels. The Estonian spatial planning system is decentralised in the way that local governments have major responsibilities regarding the planning and implementing of the ecological network concept. A well-functioning stakeholder network and an adequate basis of relevant information are among key factors for safeguarding the quality of land use decisions made by local government. We do not have a reason to doubt if local level decision-makers have the most direct access to relevant stakeholders, but the information and knowledge base could be inadequate due to the lack of administrative coordination between upper governance levels and local and regional levels. As a result, municipalities were not motivated to integrate the ecological network into comprehensive planning documents. In the cases where they were motivated and possessed sufficient administrative capacity, implementation proved to be more effective once the ecological network was integrated into local spatial planning legislation, than was the case with implementing planning documents of higher administrative levels.

\section{Notes}

(1) The case study in Harju County was conducted as part of an international research project about stakeholder relations in ecological network implementation, entitled "Knowledge for Ecological Networks: Catalysing Stakeholder Involvement in the Practical Implementation of Ecological Networks (KEN)". The project involved six case studies from the UK, the Netherlands, Estonia, Germany, Croatia, and Switzerland. It was coordinated by the European Centre for Nature Conservation (ECNC) from 2007-2009. 


\title{
Acknowledgements
}

\section{Preparation of this article is granted by the Doctoral School of Economics and Innovation, Tallinn University of Technology, created under the auspices of Euro- pean Social Fund.}

\author{
Received 20141210 \\ Approved for publishing 20150317
}

\section{References}

Albert, C., Von Haaren, C. (2014). Implications of Allpying the Green Infrastructure Concept in Landscape Planning for Ecosystem Services in Peri-Urban Areas: An Expert Survey and Case Study. Planning Practice \& Research.

Bellandi, M., Caloffi, A. (2010). An Analysis of Regional Policies Promoting Networks for Innovation. European Planning Studies, Vol. 18 (1): 67-82.

Bennet, G. (2004). Integrating Biodiversity Conservation and Sustainable Use: Lessons learned from Ecological Networks. Gland and Cambridge: IUCN. Website: http://data.iucn.org/dbtw-wpd/edocs/2004-002.pdf [13.02.2015].

Bouckaert, G., Pollitt, C. (2004). Public Management Reform. A Comparative Analysis. 2nd edition. Oxford: Oxford University Press.

Erdmann, K. H., Brendle, U., Meier, A. (2004). Kommunikation und Kooperation, in deutsches MABNationalkomitee. UNESCO-Biosphärenreservate - Modellregionen für eine Nachhaltige Entwicklung. Berlin, Heidelberg: Springer, p. 59-65.

EC. (2011). Communication from the Commission to the European Parliament, the Council, the Economic and Social Committee and the Committee of the Regions. Our life insurance, our natural capital: an EU biodiversity strategy to 2020. Website: http://eur-lex.europa.eu/legal-content/EN/ALL/;jsessionid=v5vgTpjY V12MwQMk63n8xPY6nRFQpw0jlpGZHvhDXD1J2n2TmsmB!-488601054?uri=CELEX:52011DC0244 DoA: 13.02 .2015

EC. (2013). Communication from the Commission to the European Parliament, the Council, the European Economic and Social Committee and the Committee of the Regions "Green Infrastructure (GI) - Enhancing Europe's Natural Capital”, COM/2013/0249 final*/. Website: http:/eur-lex.europa.eu/legal-content/EN/ ALL/;jsessionid=Sny9T16GWQgp9Y7gL1QbQwP1vQ9xyB1 tgvL3qV2207pHHmv638g2!-979635541?uri =CELEX:52013DC0249 [13.02.2015].

Estonian Ministry of Environment. (2001). Estonia 2010. National Spatial Plan. Tallinn. Website: http://www. siseministeerium.ee/index.php?id=8356 [13.02.2015].

Estonian Ministry of Interior. (2013). National Spatial Plan Estonia 2030+. Tallinn. Website: https://eesti2030. files.wordpress.com/2014/02/estonia-2030.pdf [13.02.2015].

EU Committee of the Regions. (2013). Green infrastructure - enhancing Europe's natural capital, opinion. Website: https://toad.cor.europa.eu/corwipdetail.aspx?folderpath=ENVE-V/039\&id=22238 [13.02.2015].

Healey, P. (1997). Collaborative Planning. Shaping Places in Fragmented Societies. Hampshire: Palgrave.

Hooghe, L., Marks, G. (2001). Multi-level governance and European Union. Lanham: Rowman and Littlefield.

Jongman, R. H. G., Külvik, M., Kristiansen, I. (2004). European ecological networks and greenways. Landscape and Urban Planning, Vol. 68(2-3): 305-319.

Kivimaa, K. (2008). Rohestruktuuri käsitluse analüüs Eesti II ja III taseme planeeringutes [Analysis of approaches to green structure of $2^{\text {nd }}$ and $3^{\text {rd }}$ level spatial plans in Estonia] (in Estonian). Master's thesis, Estonian University of Life Sciences, Tartu. 
Koort, A. (2010). Ehitus- ja planeerimistegevusest Keila valla rohevõrgustikus [Construction and Planning Activities in the Green Network of Keila Municipality] (in Estonian). Master's thesis, Tartu College, Tallinn University of Technology, Tartu.

Külvik, M., Sepp, K., Jagomägi, J., Mander, Ü. (2003). Ecological networks in Estonia - from classical roots to current applications. In: Ü. Mander, M. Antrop (eds.). Multifunctional Landscapes, Vol. 3. Continuity and change. Series: Advances in Ecological Sciences, Vol. 16 (p. 263-298). Southampton, Boston WIT Press.

Llausas, A., Roe, M. (2012) Green Infrastructure Planning: Cross-National Analysis between North-East of England (UK) and Catalonia (Spain). European Planning Studies, Vol. 20 (4): 641-663.

Leach, W. D., Pelkey, N. W., Sabatier, P. A. (2002). Stakeholder partnerships as collaborative policymaking: evaluation criteria applied to watershed management in California and Washington. Journal of Policy Analysis and Management, Vol. 21(4): 645-670.

Lægreid, P., Rolland, V. W., Roness, P. G., Ågotnes, J. E. (2003). The Structural Anatomy of the Norwegian State 1947-2003. Paper presented at the seminar on Organizational Forms, Autonomy and Control in the Public Sector. Bergen, 1-2 December.

Lægreid, P., Verhoest, K., Jann, W. (2008). The governance, autonomy and coordination of public sector organizations. Public Organization Review, Vol. 8(2): 93-96.

Mander, Ü, Jagomägi, J., Külvik, M. (1988). Network of compensative areas as an ecological infrastructure of territories. Connectivity in Landscape Ecology. In: K. F. Schreiber (ed.). Proceedings of the $2^{\text {nd }}$ International Seminar of the International Association for Landscape Ecology, Münster 1987. Münstersche Geographische Arbeiten, 29, p. 35-38.

Niikawa, T. (2006). Decentralization and local governance: reinforcing democracy and effectiveness of local government. Regional Forum on Reinventing Government in Asia Building Trust in Government: Innovations to Improve Governance 6-8 September 2006. Seoul, Republic of Korea. Website: http://unpan1.un.org/ intradoc/groups/public/documents/un/unpan024473.pdf [13.02.2015].

Peters, B. G. (1998). Managing Horizontal Government: the Politics of Co-ordination. Canadian Centre for Management Development. Research Paper, No. 21.

Pretty, J. N., Guijt, J., Thomson, J., Scoones J. (1995). A Trainers Guide for Participatory Learning and Action. London: International Institute for Environment and Development.

Rhodes, R. A. W. (2007). Understanding governance: ten years on. Organization Studies, Vol. 28(8): $1243-1264$.

Sepp, K., Jagomägi, J. (2002). Roheline võrgustik [Green Network] (in Estonian). Eesti Vabariigi Siseministeerium.

Sepp, K., Jagomägi, J., Kaasik, A., Nikodemus, O., Kreilis, M., Strazdina, B., Busa, V., Vaiciunaite, R., Mierauskas, P., Gulbinas, Z., Ramonas, A., Kurlavicius, P., Gudžinskas, Z., Rašomavicius, P., Ivinskis, P., Kesminas, V., Mickevicius, E. (2002). Development of National Ecological Networks in the Baltic Countries in the framework of the Pan-European Ecological Network. Warsaw: IUCN Office for Central Europe.

Sepp, K., Kaasik, A. (2002). Development of National Ecological Networks in the Baltic Countries in the Framework of the Pan-European Ecological Network. Warsaw: IUCN Office for Central Europe.

Sepp, K., Külvik, M. (2009). Estonia: the Green Network. In: K. Sundseth, A. Sylwester (eds.). Towards Green Infrastructure for Europe. Integrating Natura 2000 sites into the wider countryside. Proceedings of the European Commission workshop, Brussels, 25-26 March 2009, p. 27-28.

Tani, A. (2007). Rohevõrgustiku teemaplaneeringu rakendusmise analüüs Harju maakonna ja Keila valla näidetel [The Analysis of thematic planning of the Green Network with examples from Harju County and Keila Rural Municipality]. (In Estonian). Bachelor's thesis, Estonian University of Life Sciences, Tartu.

Tieman, S., Silbert, R. (2009). Ecological networks implemented by participatory approaches as a response to landscape fragmentation. Outlook on Agriculture, Vol. 38(2): 205-212.

United Nations Economic Commission for Europe. (2008). Spatial Planning. Key Instrument for Development and Effective Governance. New York, Geneva: United Nations.

Wallace, H., Pollack, M. A., Young, A. R. (2010). Policy-Making in the European Union. Oxford: Oxford University Press. 